\title{
Rangeliosis: histopathological analysis, hematology and molecular detection of canine Rangelia vitalii in Rio Grande do Sul, Brazil
}

\author{
Gabriela Fredo $^{1}$ Ronaldo Viana Leite-Filho ${ }^{1}$ Camila De Ávila Pietzsch $^{1}$ \\ Caroline Pinto de Andrade ${ }^{1}$ Naila Cristina Blatt Duda ${ }^{2}$ Lismara Castro do Nascimento ${ }^{1}$ \\ Stella de Faria Valle ${ }^{2}$ João Fábio Soares ${ }^{3}$ Luciana Sonne $^{1^{*}}$
}

${ }^{1}$ Setor de Patologia Veterinária (SPV), Faculdade de Veterinária, Universidade Federal do Rio Grande do Sul (UFRGS), Avenida Bento Gonçalves, 9090, 91540-000, Porto Alegre, RS, Brasil. E-mail: lusonne@yahoo.com.br. "Corresponding author.

${ }^{2}$ Laboratório de Análises Clínicas Veterinárias (LACVET), Universidade Federal do Rio Grande do Sul (UFRGS), Porto Alegre, RS, Brasil.

${ }^{3}$ Laboratório de Protozoologia, Faculdade de Veterinária, Universidade Federal do Rio Grande do Sul (UFRGS), Porto Alegre, RS, Brasil.

\begin{abstract}
In the period from January 2004 to December 2015, 56 dogs were diagnosed with rangeliosis in the Setor de Patologia Veterinária at Universidade Federal do Rio Grande do Sul (SPV-UFRGS). The main hematological abnormalities were thrombocytopenia and anemia. The affected dogs showed signs of apathy, anorexia, fetid and bloody diarrhea, vomiting, and dehydration. At necropsy, the main changes were jaundice, splenomegaly, hepatomegaly, and lymphadenomegaly. Histological analyses revealed parasitophorous vacuoles of Rangelia vitalii in cytoplasmic endothelial cells, mainly in the heart, kidneys, lymph nodes, intestines, and pancreas. Inflammation characterized by mononuclear cells was predominant in the analysis, and most was due to the presence of plasma cells. Other lesion types observed were lymphoid hyperplasia, extramedullary hematopoiesis, erythrophagocytosis, and erythroid lineage hyperplasia in bone marrow. Of the total number of animals, 49 were diagnosed using necropsy and histological analysis, and seven were diagnosed using a molecular analysis (i.e., PCR and genetic sequencing of blood samples). This paper presented a different method of diagnosing rangeliosis in canines. This approach involved histological methods including the quantification and determination of the intensity and distribution of the infectious agent in different organs.
\end{abstract}

Key words: canids, hemoparasite, nambyuvú, Rangelia vitalii, rangeliosis.

Rangeliose: achados anatomopatológicos, hematológicos e deteç̧ão molecular de Rangelia vitalii em cães no Rio Grande do Sul, Brasil

RESUMO: No periodo de janeiro de 2004 a dezembro de 2015, 56 caninos domésticos obtiveram o diagnóstico de rangeliose no Setor de Patologia Veterinária da Universidade Federal do Rio Grande do Sul (UFRGS). Os cães apresentaram sinais de apatia, anorexia, diarreia fétida e sanguinolenta, êmese e desidratação. As principais alterações hematológicas foram trombocitopenia e anemia. Na necropsia as principais alterações foram icterícia, esplenomegalia, hepatomegalia e linfadenomegalia. Na análise histológica observou-se vacúolos parasitóforos de Rangelia vitalii no citoplasma de células endoteliais, principalmente no coração, rins, linfonodos, intestinos e pâncreas. A inflamação mononuclear foi predominante na análise, sendo que a maioria deu-se pela presença de plasmócitos. Entre outras lesões frequentemente observadas estão hiperplasia linfoide, hematopoiese extramedular e eritrofagocitose, e hiperplasia de linhagem eritroide em medula óssea. Do total, 49 cães foram diagnosticados através de necropsia e análise histológica, e 7 animais através de análise molecular da PCR e sequenciamento genético de amostras de sangue. Este trabalho apresenta um diagnóstico diferencial de rangeliose em caninos, através do método histológico de quantificação e determinação de intensidade e distribuição do agente em diferentes órgãos.

Palavras-chave: caninos, hemoparasita, nambyuvú, Rangelia vitalii, rangeliose.

\section{INTRODUCTION}

Rangeliosis is a disease caused by the piroplasm Rangelia vitalii (SOARES et al., 2011), which occurs mainly in southern Brazil (FIGHERA et al., 2010; FRANÇA et al., 2010). In Brazil, rangeliosis is diagnosed in wild canids using PCR (SOARES et al., 2014) and macroscopic and histological analyses (FREDO et al., 2015). The disease has also been described in other countries of South America, such as Argentina (EIRAS et al., 2014) and Uruguay (SOARES et al., 2015). This piroplasm, which is transmitted by the tick Amblyomma aureolatum, can infect endothelial cells in addition to erythrocytes and leukocytes in the bloodstream (LORETTI \& BARROS, 2005; FRANÇA et al., 2010), and the major changes occur due to hemolytic and hemorrhagic disorders. 
A diagnosis of this infection is made according to historical clinical signs (LORETTI \& BARROS, 2005), peripherical blood smears (FRANÇA et al., 2010), fine needle aspiration (FNA) of lymph nodes and bone marrow, and gross and histopathological findings (LORETTI \& BARROS, 2005; FIGHERA et al., 2010;) in addition to the molecular detection and identification of the agent (SOARES et al., 2011). At necropsy, infected dogs have lesions typical of a hemolytic disorder (FIGHERA et al., 2010), as evidenced by generalized jaundice, splenomegaly, lymphadenomegaly, and hemorrhage (LORETTI \& BARROS, 2005). Upon histopathological examination, it is possible to visualize $R$. vitalii schizonts in the cytoplasm of blood capillary endothelial cells, mainly in the lymph nodes, spleen, liver, bone marrow, kidneys, and lungs (FRANÇA et al., 2010; FIGHERA et al. 2010). Recently, two real-time polymerase chain reaction (qPCR) assays have been developed to detect and quantify $R$. vitalii in the blood of dogs. One uses the 18s RNA gene fragment with SYBR ${ }^{\circledR}$ Green (PAIM et al., 2016), and the other uses a TaqMan probe (SOARES et al., 2014).

There is a need for a different method of diagnosis because of the similarity of this disease with canine babesiosis (MORITA et al., 1995; LEMOS et al., 2012). Hence, the objective of this research was to characterize cases of canine rangeliosis identified in the Setor de Patologia Veterinária at Universidade Federal do Rio Grande do Sul (SPV-UFRGS) based on epidemiology, hematology and gross and histopathology in addition to the molecular detection and sequencing of genetic material.

\section{MATERIALS AND METHODS}

Canine necropsy records were reviewed from January 2004 to December 2015. Data regarding breed, age, sex, origin, and clinical history were compiled and analyzed. For histological evaluation, paraffin-embedded tissues were selected, cut into sections with a $3 \mu \mathrm{m}$ thickness using a microtome, and stained with hematoxylin and eosin (HE). For histological analysis, the quantification of $R$. vitalii schizonts in the cytoplasm of endothelial cells was performed by counting protozoans by observing 10 random fields under a microscope at 400x magnification. Furthermore, we classified parasite quantity as mild $(+)$ when there were one to five parasitophorous vacuoles, moderate $(++)$ when there were from five to ten, and marked $(+++)$ when there were more than 10 parasitophorous vacuoles of $R$. vitalii. Fresh EDTA-anticoagulated blood samples were submitted for routine blood analysis. All samples were analyzed using ProCyte Dx (Idexx Laboratories, USA), in which the evaluated variables included a complete blood cell count (CBC) that consisted of a white blood cell count (WBC), hemoglobin (MCH), red blood cell count (RBC), and platelet count (PLT), as well as reticulocyte counts. For all samples, a 200cell manual differential count, packed cellular volume (PCV), and PLT were also determined. Plasma total protein (TP) levels were determined using refractometry. Albumin levels was measured using a CM 200 clinical analyzer (Wiener Lab), an automated spectrophotometer, and commercial kits (Labtest, Brazil). Blood samples from seven suspect dogs that were attended at the Veterinary Clinic Hospital - UFRGS (HCV-UFRGS) were also analyzed using conventional PCR for protozoan detection. These samples were designed for total DNA extraction using a QIAamp DNA Mini Kit (Qiagen ${ }^{\circledR}$ ) according to the manufacturer's instructions. The PCR reaction was performed using primers described by SOARES (2011). The following primers were used: BAB143167 (5'-CCGTGCTAATTGTAGGGCTAATACA-3') and BAB694-667 (5'-GCTTGAAACACTCTARTTTTCTCAAAG-3'). Primers were used at a concentration of $30 \mathrm{pmol}$ each to amplify a 550-bp fragment of the $18 \mathrm{~S}$ rRNA gene from piroplasmids. The PCR reaction comprised the following parameters: $95^{\circ} \mathrm{C}$ for $5 \mathrm{~min}$ followed by 35 cycles of $95^{\circ} \mathrm{C}$ for $30 \mathrm{sec}, 58^{\circ} \mathrm{C}$ for $30 \mathrm{sec}$, and $72^{\circ} \mathrm{C}$ for $45 \mathrm{sec}$, and a final step of $72^{\circ} \mathrm{C}$ for $5 \mathrm{~min}$. TaqPlatinum polymerase (Invitrogen) was used. PCR products were sequenced in an automated sequencer using a BigDye Terminator version 3.1 Cycle Sequencing kit and run on an ABI PRISM 3130 Genetic Analyzer (Applied Biosystems). Results of the chromatograms were analyzed using the software package Staden version 1.7.0 (STADEN et al., 2003). Sequences obtained were subjected to BLAST analysis (ALTSCHUL et al., 1990) for verification of sequence similarity in GenBank and confirmation of infectious agent identity.

\section{RESULTS AND DISCUSSION}

Of the 5613 dog necropsies analyzed during this period, there were 49 diagnoses of rangeliosis $(0.87 \%)$. A diagnosis of rangeliosis was based on a necropsy and histological and hematological findings. In addition to necropsies, we submitted blood samples from seven dogs for molecular diagnosis at the SPV-UFRGS. Thus, a 
total of 56 cases were diagnosed with rangeliosis. The dogs originated from the HCV-UFRGS and private veterinary clinics in the Porto Alegre metropolitan region as well as Caxias do Sul city. The age was reported in $80 \%$ of the cases and ranged from 2 months to 12 years (mean age of 5.3 years). Most of the dogs were young, from 2 months to 4 years old, similar to FIGHERA et al. (2010). Of the 56 dogs, $60 \%$ were male and $40 \%$ were female. Although a higher frequency of the disease has been reported in males, there are no studies demonstrating a sexual predisposition (FRANÇA et al., 2014).

The breed of the dog was reported in $98 \%$ of the cases. Mongrel dogs were the most affected $(61 \%)$ and were followed by Poodles (9.3\%), German Shepherds (7.4\%), Rottweilers (5.5\%) and Pit bulls (3.7\%). The other breeds presented one case each: Brazilian Fila, Labrador, Lhasa Apso, Collie, Dachshund, Dalmatian, Schnauzer, Border Collie, and Breton Spaniel. There was no evidence of a predisposition regarding the breed (FIGHERA et al., 2010), but mongrel dogs were the most described, a fact attributed to the high frequency of medical care required for these dogs in HCVUFRGS. Of the animals analyzed, $86 \%$ were living in urban areas, and $14 \%$ lived in rural and periurban areas. Forty-nine percent of the diagnoses occurred in the summer, $35 \%$ occurred in the spring, and the remaining were not reported. The main period of occurrence of the disease was from December to March, possibly due to increased numbers of vectors in the environment (LORETTI \& BARROS, 2005).

The main clinical signs observed were apathy, hyporexia, anorexia, dehydration, epistaxis, skin petechiae, and copious bleeding of the ears. Clinical evaluation of the animals revealed jaundice or pallor, and petechiae were observed in the mucous membranes. Hematochezia was observed in $51 \%$ of the dogs, $24 \%$ showed fetid diarrhea, and $16 \%$ presented orange urine. Clinical suspicion was mentioned in $71 \%$ of the cases, including suspicion of leptospirosis, hemoparasitoses, intoxication, distemper, babesiosis, hepatopathy, parvovirosis, and leishmaniasis. Rangeliosis was suspected in only three cases. Regarding clinical signs, apathy was initially observed in $77 \%$ of the dogs and was followed by hyporexia (57\%) and anorexia (36\%). These data are in agreement with those of FIGHERA et al. (2010), who also reported the same signs. Those authors also claimed that during the acute phase of the disease, the animals presented fever and pale or yellow mucous membranes. Severe bilateral hemorrhage of the pinnae is considered a characteristic of the disease and was observed in $14.3 \%$ of the cases, in agreement with the results of other authors (FIGHERA et al., 2010). The animals presented gastroenteric symptoms such as emesis and bloody diarrhea, which were also reported by other authors (FIGHERA et al., 2010; FRANÇA et al., 2010; DA SILVA et al., 2011).

A macroscopic evaluation revealed that $31 \%$ of the specimens had ticks, which were not identified. Regarding the body condition of the animals, $40.8 \%$ were thin, $24.5 \%$ had a normal body condition, $18 \%$ were very thin, $6.1 \%$ were overweight, and the remaining were not reported. In $14.3 \%$ of the cases, there were clots in the pinnae due to bleeding of the ears. The oral mucosa (Figure 1A) and conjunctival mucosa were icteric in $89 \%$ of the cases. Mild jaundice with petechial hemorrhages in the oral mucosa were reported in $10 \%$ of the specimens, and $34 \%$ of the dogs had mucosal paleness, marked bilateral epistaxis $(2 \%)$, and subcutaneous $(12.2 \%)$ and pelvic (4\%) edema.

The main gross changes are shown in table 1 . Gross changes such as jaundice, hepatomegaly, splenomegaly, and lymph node enlargement were reported in the present study as well as in studies by other authors (LORETTI \& BARROS, 2005; FIGHERA et al., 2010). Splenomegaly (Figure 1B) was observed in all cases and reported to be an important finding for diagnosing the disease (FIGHERA et al., 2010; DA SILVA et al. 2011; FRANÇA et al., 2014). Hepatomegaly was also common and was present in $89 \%$ of the dogs, which corroborates the reports in other studies (FIGHERA et al., 2010; DA SILVA et al., 2011;). Necropsy examination revealed livers varying in color shade, with $41 \%$ presenting as diffusely orange. Similar findings have been described by other authors (FIGHERA et al., 2010). The gallbladder in 32\% of the animals had a thickened wall and bile with a lumpy consistency, and in $7 \%$ of the dogs, the wall was thickened with edema and dilated due to the large amount of bile, which corroborates FIGHERA et al. (2010). Lymphadenomegaly was a relevant alteration and is important in gross characterizations of rangeliosis, as has been described in other studies (FIGHERA et al., 2010; DA SILVA et al., 2011;). FIGHERA et al. (2010) evaluated 35 dogs that were naturally infected with $R$. vitalii and observed mild to severe hemorrhage in all animals that was commonly observed in the mucous membranes and/ or skin in addition to organs such as the intestines, 


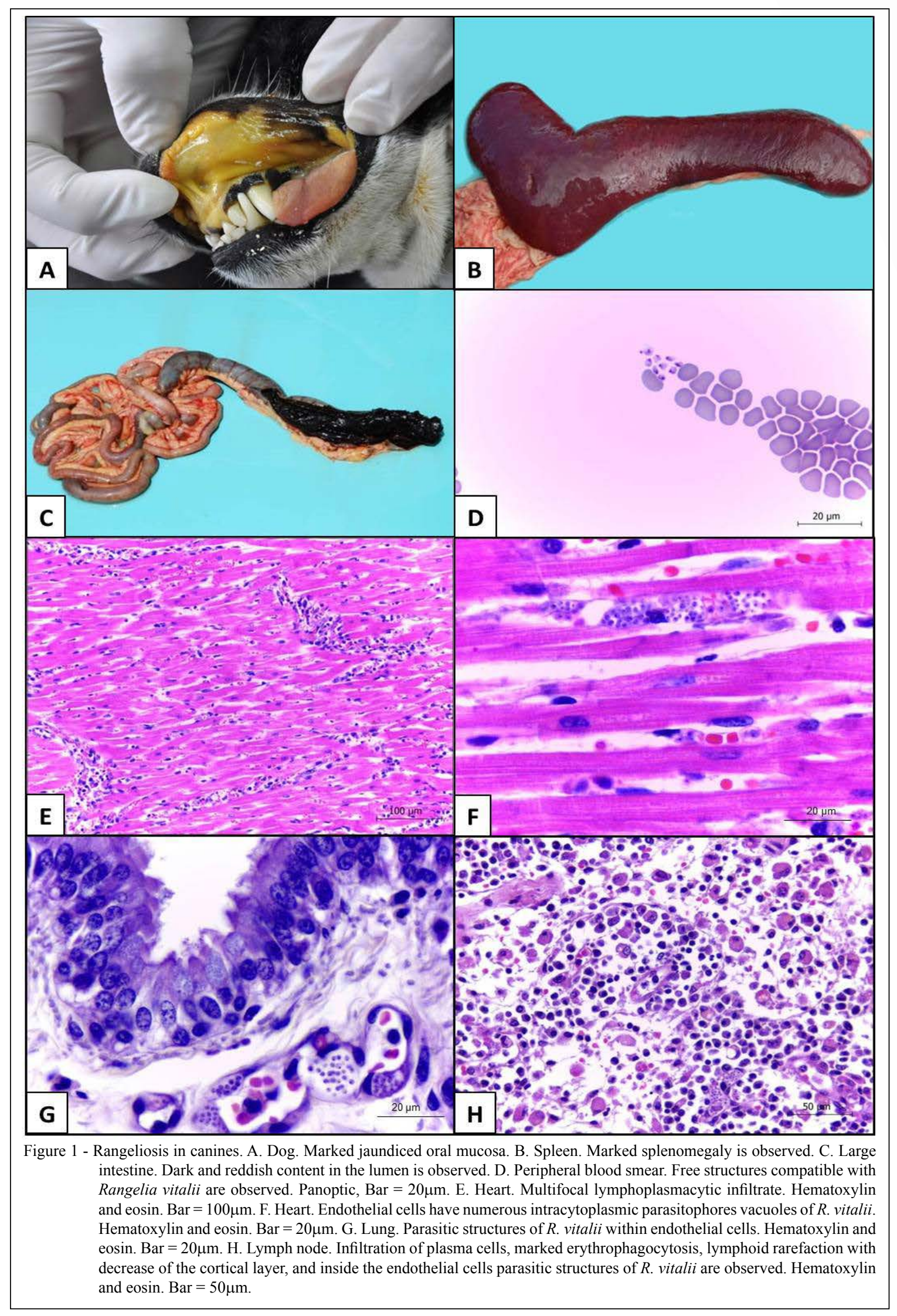

Ciência Rural, v.47, n.10, 2017. 
Table 1 - Main macroscopic alterations observed in 49 naturally infected Rangelia vitalii dogs diagnosed in the SPV-UFRGS.

\begin{tabular}{|c|c|c|c|}
\hline & Organ & Gross lesion & Percentage $(\%)^{*}$ \\
\hline \multirow[t]{16}{*}{ Abdominal cavity } & Spleen & Splenomegaly & 100 \\
\hline & Liver & Hepatomegaly & 90 \\
\hline & & Alteration in color & 90 \\
\hline & & Obvious lobular pattern & 47 \\
\hline & Gallbladder & Thickened wall and bile of lumpy consistency & 29 \\
\hline & Lymph node & Lymphadenomegaly & 83 \\
\hline & Small intestine & Mucosal bleeding & 59.1 \\
\hline & & Melena & 51 \\
\hline & Large intestine & Hematochezia & 61 \\
\hline & & Mucosal bleeding & 35 \\
\hline & Stomach & Mucosal bleeding & 59 \\
\hline & Kidney & Hemorrhage & 22.3 \\
\hline & Bladder & Petechiae in the mucosa & 10.2 \\
\hline & & Urine of orange coloration & 4.1 \\
\hline & Pancreas & Hemorrhage & 8.2 \\
\hline & Lung & Edema & 63 \\
\hline \multirow[t]{2}{*}{ Thoracic cavity } & Heart & Multifocal reddish areas & 10.2 \\
\hline & & Hemorrhage & 32 \\
\hline
\end{tabular}

${ }^{*}$ The percentage $(\%)$ was calculated based on the totality of the cases $(\mathrm{N}=49)$.

stomach, bladder, pancreas, lungs, and heart, and also observed in this study (Figure 1C). Regarding pulmonary alterations, $63 \%$ had edema, and FIGHERA et al. (2010) observed that in all cases where a gross diagnosis was made, pulmonary edema was present.

Of the 56 animals selected for the study, 17 were evaluated through hematology and albumin dosage. Hematologic abnormalities included hypochromic macrocytic anemia (47\%), normochromic normocytic anemia (29.4\%), normochromic macrocytic anemia $(5.9 \%)$, and hypochromic normocytic anemia (5.9\%), and two animals $(12 \%)$ presented PCV values at the lower reference limit. Regarding these findings, SOARES (2014), observed that the majority of dogs in their study presented normochromic normocytic anemia without significant changes in hematimetric indices. The same type of anemia has already been described by other authors (FRANÇA et al., 2010; 2013). Forty-one percent of reticulocytes were e regenerative. Hemolytic anemias are known to occur as a result of erythrocyte destruction and removal from the bloodstream prior to the end of the normal lifespan. These erythrocytes may be lysed in circulation (intravascular hemolysis), or lysis may occur in the phagocytic cells of the mononuclear phagocytic system (extravascular hemolysis) (FRANÇA et al., 2013).
In rangeliosis, hemolytic anemias are mainly regenerative if there is sufficient time for adequate bone marrow response, in our study, $41 \%$ of the dogs evaluated had regenerative anemia, $12 \%$ had weakly regenerative anemia, and $6 \%$ had non-regenerative anemia. Evaluation of platelet indexes showed that in all cases, there was thrombocytopenia, which ranged from 18.000 to 180.000 platelets $\mu \mathrm{L}^{-1}$. SOARES (2014), demonstrated that all inoculated dogs presented an abrupt reduction in platelet counts at 5 to 6 days post-infection, while those infected with ticks showed thrombocytopenia between 13 and 19 days post-infection. This author also observed that the reduction of platelets occurred very close to the detection of the agent by PCR ( 3 to 4 days in inoculated dogs and 10 to 14 days in infested dogs). CARINI (1948) suggested that the vascular endothelial injury and infection stage refers to the pre-erythrocyte phase and that thrombocytopenia in parasitized dogs results from platelet consumption by protozoa that are exiting cytoplasmic endothelial cells. Furthermore, in the current study, two animals with structures compatible with free piroplasmids in the blood were documented (Figure 1D).

Protein and albumin levels were only reported in ten analyses (59\%), of which six dogs showed hypoproteinemia and hypoalbuminemia. Hypoalbuminemia was observed in $35.4 \%$ of the 
dogs and may be related to inflammation caused by the presence of the protozoan because albumin is an acute-phase negative protein that tends to show reduced serum levels after an inflammatory stimulus (CERÓN et al., 2005).

In $94.12 \%$ of the animals (16/17), neutrophilic leukocytosis with regenerative left shift and lymphocytosis were observed in addition to eosinophilia, which was observed in $76 \%$, $(13 / 17)$ and monocytosis, which was documented in $65 \%(11 / 17)$. Two animals presented leucopenia. FIGHERA et al. (2010), observed leukocytosis in most cases, with oscillation between 18.900 and 37.200 leukocytes $/ \mathrm{mm} 3$. The same authors also noted that some animals presented leucopenia (oscillating between 2.700 and 4.100 leukocytes $\mathrm{mm}^{-3}$ of blood). Leukocytosis and leukopenia were also present in dogs naturally infected with $R$. vitalii (FRANÇA, 2010). Leukograms of dogs affected by $R$. vitalii often show leukocytosis due to neutrophilia with left-sided deviation (FIGHERA, 2007).

Furthermore, the occurrence of leukopenia was previously observed by FIGHERA et al. (2010), who associated it with eosinopenia and neutropenia, which were also observed in our animals. The authors associated leukopenia with neutropenia and eosinopenia with acute disease at the time of examination.

Histological evaluation revealed that most animals presented inflammatory infiltrates, predominantly of plasma cells and lymphocytes, in the kidneys $(88 \%)$, stomach $(86 \%)$, heart $(82 \%)$ (Figure 1E), lungs (78\%), pancreas 62\%), small intestine $(59.2 \%)$, large intestine $(51 \%)$, bladder (37\%), adrenal gland (33\%), and skin (29\%). In some organs, such as the kidneys (4\%), adrenal gland $(6 \%)$, small intestine $(4 \%)$, and heart $(6 \%)$, macrophage infiltrate was observed. In the heart, there were hemorrhagic areas in the epicardium and myocardium (27\%) and cardiomyocyte necrosis $(8.2 \%)$. Histopathological analysis made it possible to observe and quantify parasitophorous vacuoles containing $R$. vitalii schizonts within the cytoplasm of capillary endothelial cells in several organs (Table 2). In the histopathological evaluation performed using an oil immersion objective $(1000 \mathrm{X})$, we observed round to oval structures, which had pale blue cytoplasm and a violaceous nucleus and measured approximately $2.0-2.5 \mu \mathrm{m}$, all of which are characteristics that are compatible with $R$. vitalii (Figures $1 \mathrm{~F}, 1 \mathrm{G}$ and $1 \mathrm{H}$ ). This infection was particularly intense in the heart, kidneys, lymph nodes, intestines, and pancreas, with the heart showing the highest number of parasites per field. In other studies, the organs with the highest burden of $R$. vitalii based on histology were the lymph nodes, spleen, liver, bone marrow, kidneys, tonsils, stomach, intestines, heart, lungs, and, less frequently, the skin, muscles, choroid plexus, and adrenal glands (FIGHERA et al., 2010; FRANÇA et al., 2014).

The histological lesions observed in the spleen included extramedullary hematopoiesis $(63.3 \%)$, erythrophagocytosis $(57 \%)$, lymphoid hyperplasia (55\%), central follicular necrosis (49\%), lymphoid rarefaction (45\%), hemosiderosis $(37 \%)$, and inflammatory infiltrate of plasma cells $(6 \%)$. In the spleen, standard histological lesions were repeatedly observed in most cases, with red pulp hyperplasia due to increased cellularity and marked proliferation of plasma cells and their precursors. Extramedullary hematopoiesis (mainly erythropoiesis and megakaryocytopoiesis) and erythrophagocytosis were reported by other authors (FIGHERA et al., 2010; DA SILVA et al., 2011). Lymphoid histology is characterized by lymphoid rarefaction (71\%), erythrophagocytosis (65\%), inflammatory infiltrate in plasma cells (47\%), lymphoid hyperplasia (8.2\%) and central follicular necrosis (8.2\%). In the lymph nodes, FIGHERA el al. (2010) observed mainly lymphoid hyperplasia, and macrophages were observed in erythrophagocytosis in the medullary sinuses. Hepatic abnormalities were characterized by hepatocyte cord atrophy $(53 \%)$, fatty degeneration $(27 \%)$, centrilobular necrosis (22\%), erythrophagocytosis (25\%), hemosiderosis (22\%), cholestasis $(20 \%)$, and extramedullary hematopoiesis (18\%). FIGHERA et al. (2010) analyzed the livers of 35 dogs, and 33 exhibited randomly localized inflammation. Most could be visualized in the portal spaces surrounding the bile ducts. The liver may have centrilobular or paracentral coagulative necrosis, accumulated bile pigment (mainly within the bile canaliculus), and extramedullary erythropoiesis of varying intensity. Hepatocyte atrophy was the most observed lesion type and was followed by diffuse congestion and fatty degeneration. Central lobular necrosis and hepatocyte cord atrophy can be explained by anemia (McGAVIN \& ZACHARY, 2007).

A bone marrow analysis was performed in $49 \%$ of the dogs. Cellularity ranged from $70 \%$ to $95 \%$ when all the lines were analyzed. Erythrocytic hyperplasia was observed in $67 \%$ of the animals, megakaryocytic hyperplasia in $17 \%$, and myeloid 
Table 2 - Quantification of Rangelia vitalii in different organs of naturally infected dogs that were necropsied in the SPV-UFRGS.

\begin{tabular}{|c|c|c|c|c|c|}
\hline Organ & $(+)$ & $(++)$ & $(+++)$ & (ND) & Total evaluated \\
\hline Heart & 8 & 9 & 30 & - & 47 \\
\hline Lung & 26 & 6 & 9 & 7 & 48 \\
\hline Kidney & 25 & 8 & 8 & - & 41 \\
\hline Spleen & 33 & 1 & 1 & 5 & 40 \\
\hline Small intestine & 13 & 10 & 14 & - & 37 \\
\hline Lymph node & 14 & 14 & 7 & - & 35 \\
\hline Pancreas & 9 & 8 & 18 & - & 35 \\
\hline Large intestine & 15 & 8 & 5 & - & 28 \\
\hline Brain & 23 & 4 & 1 & - & 28 \\
\hline Liver & 20 & 1 & 0 & 7 & 28 \\
\hline Bone marrow & 3 & 5 & 2 & 15 & 25 \\
\hline Adrenal & 12 & 6 & 6 & - & 24 \\
\hline Stomach & 2 & 10 & 10 & - & 22 \\
\hline Bladder & 14 & 3 & 4 & - & 21 \\
\hline Thyroid & 3 & 6 & 11 & - & 20 \\
\hline Cerebellum & 16 & 2 & 1 & - & 19 \\
\hline Skin & 7 & 2 & 5 & - & 14 \\
\hline Tonsil & 4 & 2 & 2 & - & 8 \\
\hline Testicle & 6 & 1 & 0 & - & 7 \\
\hline Salivary gland & 3 & 1 & 3 & - & 7 \\
\hline Skeletal muscle & 4 & 1 & 2 & - & 7 \\
\hline Prostate & 5 & 1 & 0 & - & 6 \\
\hline Parathyroid & 2 & 1 & 3 & - & 6 \\
\hline Thymus & 1 & 1 & 2 & - & 4 \\
\hline Celiac nerve & 1 & - & 3 & - & 4 \\
\hline Spinal cord & 2 & 1 & 0 & - & 3 \\
\hline Eye & 1 & - & 1 & - & 2 \\
\hline
\end{tabular}

$(+)$ mild. $(++)$ moderate. $(+++)$ marked. $(\mathrm{ND})$ R. vitalii not detected. ${ }^{*} \mathrm{~N}=49$ cases.

hyperplasia in $8.3 \%$. The myeloid-erythroid estimate ratio was increased in $42 \%$ of the animals. The platelet estimate was performed using a 100x objective, and the results ranged from three to 15 , with a mean of 5.4/100x. In $17 \%$ of bone marrow analyses, there was ordered platelet maturation. Other findings included hemosiderosis $(21 \%)$, dysplasia of myeloid lineage $(17 \%)$, dysplasia of erythroid lineage (13\%), myelophthia $(17 \%)$, necrosis $(17 \%)$, moderate lymphocytes $(17 \%)$, a marked quantity of segmented neutrophils $(8.3 \%)$, megakaryoblasts $(8.3 \%)$, and blasts $(8.3 \%)$. In the bone marrow, there was marked hyperplasia of the lineages, mainly including erythroid and megakaryocytic cells, and a decrease in the myeloid/erythroid ratio, in that adipose tissue was replaced by hematopoietic cells with a high mitotic rate and an increase number of megakaryocytes and megakaryoblasts (LORETTI \& BARROS, 2005; FIGHERA et al., 2010).
The histological findings in the kidney corroborated the results of FIGHERA et al. (2010), who observed interstitial lymphoplasmacytic inflammation confined to the cortex, degeneration and necrosis, and a variable accumulation of hemosiderin. In the lungs, we observed alveolar edema $(61.4 \%)$ ranging from mild to severe, emphysema (31\%), and thickening of the alveolar septa (37\%) with mononuclear infiltrate. FIGHERA et al. (2010) described alveolar septal thickening caused by mononuclear cells, mainly macrophages, in erythrophagia, a finding that was also observed in the current study.

PCR results were positive for $R$. vitalii in all seven blood samples (100\%). Samples were submitted to sequencing to confirm these diagnoses. After sequencing, each sample was analyzed using BLAST, and all showed 99\% homology with the $18 \mathrm{~S}$ rRNA gene of a $R$. vitalii from Argentina that was deposited in GenBank (KF218606.1) $(<\mathrm{http}: / /$ 
www.ncbi.nlm. Nih.gov/genbank/>). A molecular genetic study of $R$. vitalii was recently proposed by SOARES et al. (2011), in which the authors performed a molecular analysis and sequenced gene fragments of the $18 \mathrm{~S}$ rRNA and $h s p 70$. The analysis concluded that $R$. vitalii is a valid piroplasmid species. The sequence for the $R$. vitalii $18 \mathrm{~S}$ rRNA (GenBank No. HQ150006) that was obtained by SOARES et al. (2011) has been used as a reference for the molecular identification of $R$. vitalii in the blood of domestic and wild canids.

\section{CONCLUSION}

In this research, we presented pathological findings of canine rangeliosis. The main clinical symptoms included apathy, hyporexia, anorexia, dehydration, epistaxis, skin petechiae, and ears bleeding. We noted for epidemiological purposes that the animals in this study came mainly from the city of Porto Alegre, and we draw attention to the identification of one case in the region of Serra Gaúcha, where the disease had not previously been confirmed. In addition, our study raised the hypothesis that this disease in areas other than rural areas, which has not been mentioned by other authors. The most common hematological alterations were thrombocytopenia and anemia, and the most common gross lesions were jaundice, splenomegaly, hepatomegaly, and lymphadenomegaly. Histologic findings revealed lymphoplasmacytic infiltrate in several organs, extramedullary hematopoiesis and erythrophagocytosis in the spleen, lymph nodes, and liver, and erythroid hyperplasia in the bone marrow. In relation to histological quantifications of $R$. vitalii, we concluded that the heart, kidneys, lymph nodes, intestines, and pancreas were the most parasitized and that the heart was the organ with the highest burden of $R$. vitalii infestation. We used PCR to confirm a diagnosis of rangeliosis in blood samples, and we suggested that this method could serve other purposes, such as treatment monitoring and epidemiological studies.

\section{ACKNOWLEDGEMENTS}

The authors thank Conselho Nacional de Desenvolvimento Científico e Tecnológico ( $\mathrm{CNPq}$ ) for the indispensable funding source and support for this research.

\section{REFERENCES}

ALTSCHUL, S.F. et al. Basic local alignment search tool. Journal of Molecular Biology, v.215, n.3, p.403-410, 1990. Available from: $<$ https://publications.mpi-cbg.de/Altschul_1990_5424.pdf $>$. Accessed: Mar. 12, 2016.

CARINI, A. Sobre o ciclo de desenvolvimento exoeritrocitário de um piroplasma do cão. Arquivos do Instituto Biológico, São Paulo, v.285, p.49-52, 1948.

CERÓN, J.J. et al. Acute phase proteins in dogs and cats: current knowledge and future perspectives. Veterinary Clinical Pathology, v.34, p.85-99, 2005. Available from: <https://www. ncbi.nlm.nih.gov/pubmed/15902658>. Accessed: Mar. 12, 2016.

DA SILVA, A.S. et al. Experimental infection with Rangelia vitalii in dogs: acute phase, parasitemia, biological cycle, clinical-pathological aspects and treatment. Experimental Parasitology, v.128, n.4, p.347-352, 2011. Available from: <http://www.sciencedirect.com/ science/article/pii/S0014489411001494?via\%3Dihub>. Accessed: Mar. 12, 2016

EIRAS, D.F. et al. First report of Rangelia vitalii infection (canine rangeliosis) in Argentina. Parasitology International, v.63, p.729-734, 2014. Available from: < https://www.ncbi.nlm.nih.gov/ pubmed/24970768>. Accessed: Mar. 12, 2016.

FIGHERA, R. et al. Patogênese e achados clínicos, hematológicos e anatomopatológicos da infecção por Rangelia vitalii em 35 cães (1985-2009). Pesquisa Veterinária Brasileira, v.30, n.11, p.974-987, 2010. Available from: <http://www.scielo.br/scielo. php?script $=$ sci_arttext\&pid $=$ S0100-736X2010001100012>. Accessed: Mar. 12, 2016.

FRANÇA, R.T. et al. Rangelia vitalii in dogs in southern Brazil. Comparative Clinical Pathology, v.19, p.383-387, 2010.

FRANÇA, R.T. et al. Hematologic and bone marrow changes in dogs experimentally infected with Rangelia vitalii. Veterinary Clinical Pathology, v.42, p.31-39, 2013.

FRANÇA, R.T. et al. Canine rangeliosis due to Rangelia vitalii: from first report in Brazil in 1910 to current day - A review. Ticks and Tick-Borne Diseases, v.5, p.466-474, 2014.

LEMOS, T.D. et al. Detection and molecular characterization of piroplasms species from naturally infected dogs in southeast Brazil. Revista Brasileira de Parasitologia Veterinária, v.21, n.2, p.137-142, 2012. Available from: <https://www.ncbi.nlm.nih. gov/pubmed/22832754>. Accessed: Mar. 12, 2016.

LORETTI, A.P.; BARROS, S.S. Hemorrhagic disease in dogs infected with an unclassified intraendothelial piroplasm in southern Brazil. Veterinary Parasitology, v.134, p.193-213, 2005. Available from: <https://www.ncbi.nlm.nih.gov/pubmed/16153781>. Accessed: Mar. 12, 2016.

McGAVIN, M.D.; ZACHARY, J.F. Pathologic basis of veterinary disease. 4.ed. St. Louis: Mosby Elsevier, 2007. 1475p.

MORITA T. et al. Reactivity of anti-erythrocyte antibody induced by Babesia gibsoni infection against aged erythrocytes. Veterinary Parasitology, v.58, n.4, p.291-299, 1995. Available from: <https:// www.ncbi.nlm.nih.gov/pubmed/8533268>. Accessed: Dec. 20, 2016.

PAIM, F.C. et al. Development of a quantitative PCR for the detection of Rangelia vitalii. Veterinary Parasitology, v.217, p.113-117, 2016. Available from: <https://www.ncbi.nlm.nih.gov/ pubmed/26827871>. Accessed: Dec. 20, 2016. 
SOARES, J.F. et al. Detection and molecular characterization of a canine piroplasm from Brazil. Veterinary Parasitology, v.180, n.3, p.153-167, 2011. Available from: <https://www.ncbi.nlm.nih. gov/pubmed/21489694>. Accessed: Mar. 12, 2016.

SOARES, J.F. História natural da rangeliose. 2014. $123 \mathrm{f}$. Tese (Doutorado em Doenças Parasitárias) - Faculdade de Medicina Veterinária e Zootecnia, Departamento de Medicina Veterinária Preventiva e Saúde Animal, Universidade de São Paulo, SP.

SOARES, J.F. et al. Natural infection of the wild canid, Cerdocyon thous, with the piroplasmid Rangelia vitalii in Brazil. Veterinary
Parasitology, v.202, n.3-4, p.156-163, 2014. Available from: $<$ https://www.ncbi.nlm.nih.gov/pubmed/24685025>. Accessed: Mar. 12, 2016.

SOARES, J.F. et al. Molecular detection of Rangelia vitalii in domestic dogs from Uruguay. Veterinary Parasitology, v.210, n.1-2, p.98-101, 2015. Available from: <https://www.ncbi.nlm.nih. gov/pubmed/25843009>. Accessed: Mar. 12, 2016.

STADEN, R. et al. Managing sequencing projects in the GAP4 environment. In: KRAWETZ, S.A.; WOMBLE, D.D. Introduction to bioinformatics: a theoretical and practical Approach. Totawa, New Jersey: Human, 2003. p.327-344. 